\title{
A METHOD OF ANALYSIS OF ACTS OF UNLAWFUL INTERFERENCE IN CIVIL AVIATION
}

This article aims to present a model of civil aviation security systems in Poland as well as the original model of analysis of the acts of unlawful interference in air travel in J. Reason's theory, the so called "Swiss cheese model", specially adopted for this purpose. An analytical approach requires defining an interferential safety subject in air travel, characteristics of the security system and its constitutional elements, as well as denoting the catalogue of the acts of unlawful interference, which constitute the introduction to the model of their analysis.

\section{SECURITY IN CIVIL AIR TRAVEL}

The issue of safety in civil aviation goes back earlier in time than when the plane became the instrument for fast transfer over vast distances, so before air travel was born. Nevertheless, operational safety has been a priority, and a successful take-off and landing have designated this term. However, the 1960s of the previous century introduced a new, constantly evolving paradigm. The aircraft has become an instrument of exerting pressure and political struggle, achieving particularistic goals and satisfying the interests of individuals, groups and even states. Man, up in the skies, can feel free, but can he have a sense of safety as well? This dilemma has become a paradigm of contemporary reality after the critical September 11, 2001, having nothing to do with mythology. It was not Icarus's carelessness or a carefree desire "to taste freedom", not technological factors but unprecedented deliberate action and aim to treat aircrafts as the useful instrument for extermination and political struggle. From that moment on, the reversed proportion has had its effect: the increase of security entails restriction of freedom, paradoxically, to obtain freedom from danger. The act of terrorism has determined the approach to security in air travel and some models of security systems have been introduced. As the experience of the countries, i.e. the United States or Israel shows, despite several years of experience and funds allocated for this purpose, they are not able to entirely prevent the threat of using methods of terrorism in air travel. There is no perfect system which could prevent terrorist attacks; only their probability can be decreased. Counteracting terrorism is often associated with its physical elimination by different kinds of SWAT units, nonetheless, this is a superficial approach to this issue. Counteraction is the basis, however, its forms result from past experience and they do not involve only relatively new, or at least newly defined phenomena such as terrorism. Counteracting threats in air travel entails a broader perspective, and active operation involves the creation of security systems in order to prevent acts of unlawful interference. 
Security in air travel may be considered as referring to an individual passenger of a given flight, but it can also refer to an airline or an airport. Security in air travel can be also analysed as a specific kind of state security in cases involving the occurrence of a crisis, engaging public authorities and often even state organs of central administration and in case of undisturbed use of the airspace, it can be perceived as international security. For this classification, applying signs that specify which country an aircraft belongs to and precise, in accordance with the law, defining the conditions of extraterritoriality, seem to be crucial. Moreover, after the attacks of September $11^{\text {th }}, 2001$, security in air travel has become a priority in a global scope, although the activity of International Civil Aviation Organisation for safety in air travel had encompassed the whole globe much earlier. The designatum of safety in air travel is both operational safety, relating to flights, and safety against acts of unlawful interference or (which is not synonymous) against threats of terrorism. The differentiating approach substantiates the comparison of Polish and English terms used to define safety/security, which enables us to see, that for one Polish term (bezpieczeństwo) there are two English terms.

\section{SECURITY SYSTEM}

A system is a key issue, understood as an object, which is considered as an entirety made of the collection of elements and connections between them. A significant postulate of systematic studies is holism assuming that the reality is perceived in its entirety, and that the study of the whole makes sense. A systemic approach is focused on connections between the elements, it studies the effects of these links and is based on a general model, which can be used in the decision making process and leads to purposeful action and interdisciplinary teaching. While making use of the security system theory, the dangers (in this case the catalogue of acts understood as the acts of unlawful interference in air travel) must be identified, the effects must be analysed and assessed, security measures must be chosen and safety providing actions must be shaped - the policy of safety must be implemented (Sułek, 2004: 143-146).

Systems of safeguarding civil aviation are specific wholes denoting the collection of elements such as the safety environment, legal regulations, institutions or detailed forms of security, which guarantee to achieve a given level of safety in air travel and relationships between them. The application of systemic analysis enables us to treat an analysed phenomenon occurring in the object (political unit) as a holistic system consisting of specific subsystems and intentional use of the model of safeguarding civil aviation having a specified degree of definition in organizational and processual perspective, expressing a given aspect of action in order to obtain a desirable level of safety in air travel. The advantage of this method is the possibility of obtaining the description of homogenous characteristics of interstate systems of safeguarding civil aviation, as well as interaction between the systems, which provides the description of both positive feedback (taking over by the internal state systems the elements of other systems), and negative feedback, which means creating such an reality which is a response of international institutions (e.g. ICAO) to the appearing threats and providing stability of functioning in changing conditions, including terrorist attacks. 
As it has been indicated before, several elements can constitute an interferential security subject in air travel. In security systems of civil aviation the main position belongs to an aircraft together with its passengers and its crew. So starting with the theory human security, ${ }^{1}$ stating that a human being is the main interferential security subject in civil aviation, defining the threats relating to this subject, apart from objective perspective, will also have a subjective dimension both when referring to safety in air travel, and the condition during the actual flight. The security subject in the objective dimension is placed in the center of the security system and in a given safety environment, in which potential perpetrators of acts of the unlawful interference function as well. ${ }^{2}$

The outermost left quadrant may refer to a dangerous environment (e.g. in extreme Hobbes understanding), the right bottom - the entirely safe environment (e.g. the idealistic environment of Kant's liberalism). The remaining quadrants can denote safety environments of moderate threat. In all of these environments each element of the security system can function. The selection of security systems in air travel will be determined by the analysis of threats relating to the safety environment, having effect in motivations and actions of the perpetrator of the act of unlawful interference, the safeguarding system defined as the collection of elements of which the purpose is to detect the perpetrator being a threat to the security subject. The above is shown in the figure below.

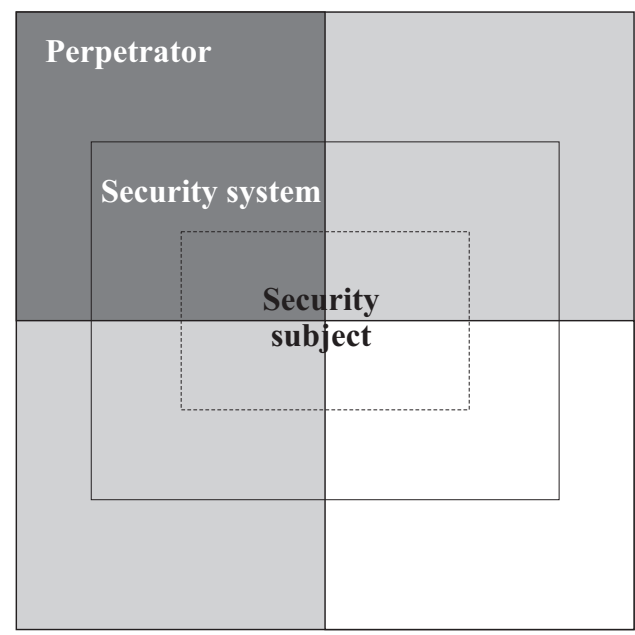

Fig. 1. Security subject in air travel in safety environment

Source: Author's own concept.

1 For theory of human security see: e.g. P. D. Wiliams, Studia bezpieczeństwa, Kraków 2012, pp. 225-237; W. Kostecki, Strach i potęga. Bezpieczeństwo międzynarodowe w XXI wieku, Warszawa 2012 , pp. 135-140.

${ }^{2}$ Motivation of a perpetrator along with the factors determining his actions is explained by the Terrorist Triad by S. Wojciechowski. See: S. Wojciechowski, Terroryzm na poczatku XXI wieku. Pojęcie, istota i przyczyny zjawiska, Bydgoszcz-Poznań 2011, pp. 113-188. 


\section{FEELING OF SAFETY AND FEAR}

A significant element which determines the level of security is the sense of safety of its subject. The safety environment, including past acts of unlawful interference in civil aviation, is bound to affect securitization (Kostecki, 2012: 112).

The fundamental issue of the creation of the subject of cognition in an epistemological perspective is incredibly complex, its boundaries are vague, which does not allow them to reflect the meaning of the phenomenon entirely. The subject must strive to create the subject of cognition to perceive it correctly, which involves allowing for the relationships between the cognitive powers and the objects, the knowledge of which is being acquired (Ziarko, 2010: 63-64). This means that two principal elements constitute safety: subjective and objective ones. The first refers to the feeling of safety, so to the inner, personal conviction that there are no reasons to fear. The latter is external in relation to the individual and involves lack of threats to their life (health, possessions). Therefore safety is a complex structure consisting of psychological and non-psychological components. In some kind of situations safety (the objective element) may not adequately correspond to the feeling of safety (the subjective component). If such a discrepancy cannot be rationally explained, then we usually deal with pathology. Its reasons may be rooted in human psyche (anxiety conditions, psychoses, mental disorders), or may derive from pathology and deviations of social culture (e.g. escalation of fear and uncertainty provoked by the media). Relationships between the reality and human psyche affect safety and result in four model state situations (Brzeziński, 2009: 26) ${ }^{3}$ :

- lack of afety in situations of significant, real danger - its perception is adequate;

- obsession - when a minor threat is perceived as enormous;

- state of false safety, when significant threat is perceived as slight;

- safety, when threat is minor and its perception correct.

Puzzling may be the scope of security measures taken in air travel in the context of a low level of threat of terrorist attack (Raport, 2012) and minor offences prevailing in this field. Such a situation requires a common and harmonized system of safeguarding civil aviation in the European Union, which Poland, being a member state thereof, is obliged to obey. Moreover, we should not exclude the possibility of an occurrence of terrorist threats, whose conducive factor remains the fact that in Poland there are people from countries and regions of increased risk. In this scope, geographical location of the Republic of Poland and legal regulations resulting from its being a member of the European Union as well as the open borders of the Schengen Area make Poland a transit country to the Western Europe for citizens of the states of increased risk. Special attention must be paid to the people staying in centers for foreigners during the procedure of granting the status of a refugee. The majority of those people are the citizens of the Russian Federation having Chechen nationality. The open character of centers for foreigners causes a lack of possibility to actually control foreigner movement, which may

3 Listed model elements are included in the theory of D. Frei. See: D. Frei, Sichetheit. Grubfragen der Eolpolitik, Stuttgart 1977, pp. 17-21. 
facilitate getting in contact or keeping in touch with radical terrorist groups operating in the Caucasus and with organized criminal groups from this area.

The state of safety of Poland and threats determine the actions taken in the field of safeguarding civil aviation. On the territory of Poland, the Head of Internal Security Agency (Pol. Agencja Bezpieczeństwa Wewnętrznego) makes the assessment of the level of terrorist threat in civil aviation on the basis of the risk analysis conducted on the grounds of their own information or on the basis of the information acquired particularly from the services responsible to the competent Minster of Internal Affairs. It may also comprise information obtained from the competent Minister of Foreign Affairs, Minister of Transport, Minister of Public Finance, Minister of Agriculture, Minister of Defence, the head of the National Atomism Agency (pol. Państwowa Agencja Atomistyki), the Chief Sanitary Inspector, and also from the structures of the European Union, ICAO and ECAC as well as their member states. Thus on the grounds of the assessment of the level of threat not only at airports but also in relation to some operations, the Head of the Civil Aviation Office may consider them to be high risk flights and introduce adequate methods and measures (not necessarily more rigorous), which should be taken in order to prevent the acts of unlawful interference.

The acts of unlawful interference constitute the conditions of security, which means the application of specific actions, methods and measures. It should be noted that the catalogue of these acts is defined and closed, and adopted norms of security understood as any provisions concerning physical characteristic, configuration, material, action, staff or procedure, and whose consistent application has been considered to be crucial for the safety or proper functioning of the international air transportation and which have been implemented regardless of the defined level of threat related to the occurrence of these attacks. Such an approach results from the definition of the acts of unlawful interference, as the act or the attempt to commit attacks aiming at putting civil aviation and air travel at risk, i.e.:

- unlawful seizure of aircraft in flight;

- unlawful seizure of aircraft on the ground;

- hostage-taking on board an aircraft or on aerodromes;

- forcible intrusion on board an aircraft, at an airport or on the premises of an aeronautical facility;

- introduction on board an aircraft or at an airport of a weapon or hazardous device or material intended for criminal purposes;

- communication of false information as to jeopardize the safety of an aircraft in flight or on the ground, of passengers, crew, ground personnel or the general public, at an airport or on the premises of a civil aviation facility (Międzynarodowe, 2011: 1).

The above catalogue of the acts of unlawful interference has been created in the framework of International Civil Aviation Organisation (ICAO), and three conventions: Tokyo, Hague and Montreal (discussed in detail in section II) forming the so-called Tokyo-Hague-Montreal system of the aviation criminal law, identified as the origin of the antiterrorist legislation. These acts are considered to be crimes without the right for asylum, which does not mean that they are terrorist attacks. 


\section{SECURITY}

In relation to the catalogue enunciated in this way, special security measures having the form of a security system are introduced, the main aim of which is to set on the way of a potential perpetrator maximum number of obstacles - elements which shall track down the perpetrator. The term "security" focuses in particular on threats. Through this operationalizational component, the level of security which is understood as an introduction of the specified forces and measurements to counter the safety threats is determined. Similarly, the safeguard in civil aviation is defined in international, community and national acts of law. Annex 17 to the Chicago Convention (ibidem) defines the safeguarding of civil aviation against the acts of unlawful interference via an aim which is reached through a combination of measures as well as human and material resources.

The European Community establishes for all the member states unified principles and common rules in the field of civil aviation security and defines them as " the combination of measures and human and material resources intended to safeguard civil aviation against the acts of unlawful interference that jeopardise the security of civil aviation" (Regulation, 2008) Civil aviation security against the acts of unlawful interference results in an introduction by the airport management and civil services security and safety systems which include (Siadkowski, 2013):

- technical protection measures including access control, passes, monitoring and technical barriers;

- physical security, including security control, facilities and areas security, aircraft security by the guards on board of aircrafts;

- intelligence activities;

- logistics subsystems including communication;

- properly trained personnel;

- rules, regulations and procedures;

- leadership and management subsystems.

A detailed description of the applied universal safety and security system of civil aviation at the state level for Poland was achieved by introducing the National Civil Aviation Security Program (Regulation, 2012) equivalent to regulation and which is an executive act of delegation of legislative powers of the Aviation Law. This regulation is closely related to the Community law, which unifies the issues regarding civil aviation security in the European Union, it is its complement, specification or it delegates in certain areas to its direct applicability. The civil aviation security in relation to the safety entity is illustrated by the figure below.

As the aim of the civil aviation protection is to provide safety for citizens by preventing the acts of unlawful interference not only in given countries but also for the international community, it has become necessary to create an institution which fulfills those functions both locally and globally. The mechanism of the functioning of institutions in democratic countries is characterized by certain legal standards which allow precise determination of the rights and obligations of the various parties involved in ensuring safety. State and non-state institutions aim to promote national values and to implement state objectives, serve its and citizens' interest and to ensure the consistency, 
Legal regulations

Airport security

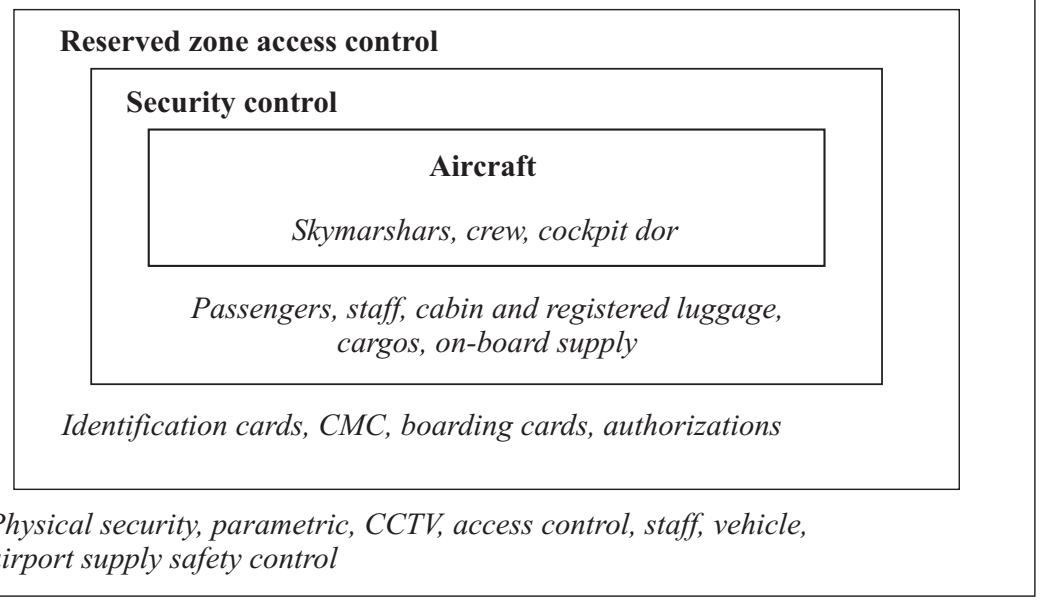

Regulating, supervising and executive institutions

Fig. 2. Civil aviation security system

Source: Author's own concept.

effectiveness and continuity of policies and actions. The variety of civil aviation activities entails the diversity of threats towards them. Therefore, the detailed executive measures should be adopted to the specific activity of the political units (states) due to their genealogy and historical experiences and to the sensitivity of the impact of certain measures. By its very nature, both institutions and legal standards on aviation security will vary from country to country. Poland, for instance, follows an example of other European Union's countries, where security control is executed by private companies acting to the benefit of the Airport Managers. The United States after September $11^{\text {th }}, 2001$, again set up the state agenda which deals with the security control - the Transportation Security Administration (TSA). After the amendment to the Act on Aviation Law and changing entity performing security checks in Poland, there was also another issue regarding supervision over those companies. On Boarder Guards, beside correction of infringement of civil aviation security and intervention measures, duties like risk analysis by investigating the background of all employees who perform security checks were imposed.

\section{THE MODEL OF ANALYSIS OF THE ACTS OF UNLAWFUL INTERFERENCE IN AIR TRAVEL}

As indicated, none of the systems can provide full security. There is a possibility that the acts of unlawful interference will occur, thus a study model over the reasons of their occurrence shall be proposed. For this purpose, the theory of James Reason was 
adopted which is the interdisciplinary approach to flight safety (Klich, 2009: 53-64). A model regarding the causes of accidents is based on the levels which generate risks concerning flight security: on the high management level, activity on low management level, factors being conducive to mistakes made by the crews, crew actions, crew supporting protective systems. In this model, graphically presented in the shape of "slices of Swiss cheese", occur areas of hidden risk (symbolically presented as holes) which appear only under certain circumstances. If these adverse circumstances occur at all levels, the accidents take place.

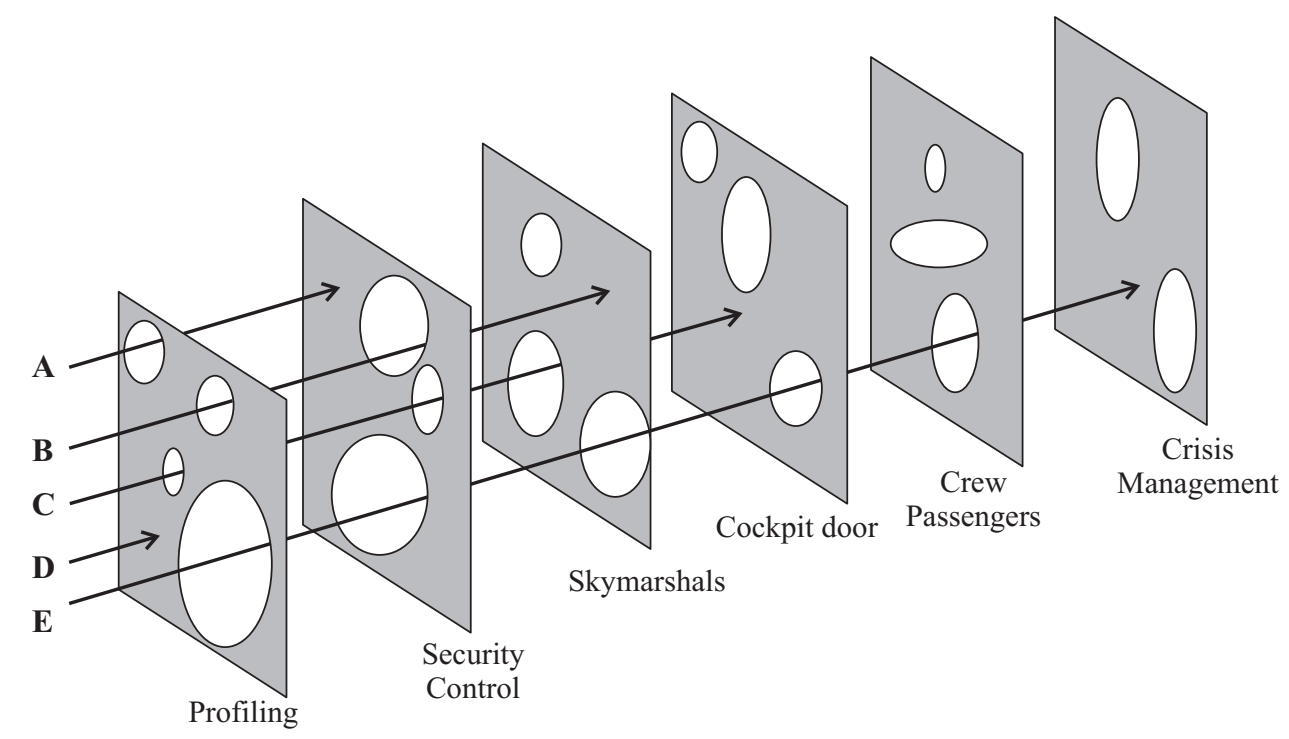

Fig. 3. Modified model of "Swiss cheese" according to J. Reason as a metaphor of safeguarding levels in civil aviation safety

Source: Author's own concept.

The model of causes of accident rates is based on security levels - structures against threats. It reflects all common elements in civil aviation security systems. In this model, which is visually presented in the form of "slices of Swiss cheese", there are areas of hidden threats (symbolically presented as holes), which emerge only in given circumstances. It is also a reflection of ideas of barriers standing in the way of a potential perpetrator. The vectors marked with the letters $(\mathrm{A}, \mathrm{B}, \mathrm{C}, \mathrm{D}, \mathrm{E})$ show the way of the potential perpetrator. The main function of different elements in the systems analysed is detection. In Israel it is assumed that "profiling" is to constitute the main aspect of security, therefore a model way of the potential perpetrator is shown by vector D. The term "profiling" includes also information acquired by the intelligence concerning threats related to air travel as well as the risk analysis conducted by the competent state authorities. In the Polish system, profiling is not a developed structure of security, thus vector A presents the way of the potential perpetrator the most correctly. The United States pays special attention to both profiling as well as security control. We cannot exclude 
the possibility that the perpetrator, due to unfavorable circumstances or a perfect plan and preparation, will find gaps in particular structures (which in system theory cannot be permanent and thus randomness and unpredictability are introduced e.g. application of a given form of safety control). The acts of unlawful interference occur on all levels. The cockpit door, in this case, denote all technological construction barriers on an aircraft, but it may also refer to a well-functioning transponder used to signal the threat of an aircraft in flight. We could finish the analysis of the causes of the act of unlawful interference on the last level of security - crew and passengers. However, the author claims that the last level of security is an effective crisis management, which in fact does not constitute the structure of security in the studies of causes, but is an important element in the general loss estimation. It may minimize the effects or in case of the act of unlawful interference such as e.g. hijacking, can contribute to releasing hostages without any casualties. History knows numerous examples of bold and successful counterterrorist actions, but also there are accounts of those which were tragic. The above model can be adjusted depending on the needs by adding or taking away relevant security levels. The idea of the model is the analysis of all security levels, not only the one, which according to a superficial opinion, could have been decisive for the committed act of unlawful interference.

$$
* * *
$$

Previous years' bitter experiences relating to the acts of unlawful interference in civil aviation, which had different grounds and were motivated differently by different perpetrators, in the modus operandi evolving in history have forced us to implement a defined security system in civil aviation. Model solutions have also been introduced almost always as a response to the occurrence of a given event or the threat of its existence. It seems that the present catalogue includes all terrorist activity known so far, which are a threat to safety in air travel, at airports, but as history shows we must also allow for appearance of totally new and unexpected threats. Even the best organized and functioning civil aviation safeguarding system will not guarantee $100 \%$ safety. Although after the attacks of September $11^{\text {th }}, 2001$ and following prevented attacks in London, a number of functional solutions have been implemented, and global, community and national institutions responsible for safety attempt to react to any threats, e.g. introducing limits on liquids brought to the reserved areas of airports and on board. It is the recent events at the airport in Burgas (Bulgaria), where a suicide bomber, right after the flight, caused the explosion of a bus with Israeli tourists, that show that safeguarding must constitute an element of the entire security system. Therefore, again the approach being the essence of ensuring safety to the subjects in civil aviation demanding constant defining threats in civil aviation in a specific safety environment, preventing them in order to maintain the risk on an acceptable level seems to be justified. In the author's opinion, in the cases of the acts of unlawful interference the presented model of explaining their causes can be a useful tool. Specialist literature presents various models of explanation of the causes of flying accidents, nevertheless there is no model accounting for the causes of the acts of unlawful interference, which do not have to result in such an accident or catastrophe. 


\title{
Bibliography
}

Brzeziński M. (2009), Kategoria bezpieczeństwa, in: Bezpieczeństwo wewnętrzne państwa. Wybrane zagadnienia, (eds.) S. Sulowski, M. Brzeziński, Warszawa.

Frei D. (1977), Sichetheit. Grubfragen der Eolpolitik, Stuttgart.

Klich E. (2009), Wykorzystanie teorii Jamesa Reasona $w$ badaniu zdarzeń lotniczych $w$ lotnictwie cywilnym, in: Bezpieczeństwo i niezawodność w lotnictwie. Air Show 2009, (ed.) B. Jancelewicz, Torun.

Kostecki W. (2012), Strach i potęga. Bezpieczeństwo międzynarodowe w XXI wieku, Warszawa.

Międzynarodowe Normy i Zalecane Metody Postępowania. Załacznik 17 do Konwencji o międzynarodowym lotnictwie cywilnym. Ochrona Międzynarodowego Lotnictwa Cywilnego przed Aktami Bezprawnej Ingerencji (2011), ICAO.

Raport o stanie bezpieczeństwa w Polsce w 2011 roku (2012), Ministerstwo Spraw Wewnętrznych, Warszawa.

Regulation (EC) No 300/2008 of the European Parliament and of the Council of 11 March 2008 on Common rules in the field of civil aviation security and repealing Regulation (EC) No 2320/2002, Official Journal of the European Union L 97, 09/04/2008 as amended.

Regulation of Minister of Transportation, Construction and Maritime Economy of 31 st July 2012 on National Civil Aviation Security Program (2012), Official Journal of the Republic of Poland, item 912.

Siadkowski A. K. (2013), Bezpieczeństwo w cywilnej komunikacji lotniczej na przykładzie Polski, Stanów Zjednoczonych i Izraela. Studium politologiczno-prawne, Szczytno.

Sułek M. (2004), Metody i techniki badań stosunków międzynarodowych, Warszawa.

Wiliams P. D. (2012), Studia bezpieczeństwa, Kraków.

Wojciechowski S. (2011), Terroryzm na poczatku XXI wieku. Pojęcie, istota i przyczyny zjawiska, Bydgoszcz-Poznań.

Ziarko J. (2010), Dylematy metodologiczne bezpieczeństwa jako nauki, in: Bezpieczeństwo. Wymiar społeczny i perspektywy badań, (ed.) M. Kwieciński, Kraków.

\begin{abstract}
This publication aims to present a model of civil aviation security system in Poland and the author's own method of analysis of acts of unlawful interference in air travel according to the theory of J. Reason (so-called "Swiss cheese method") specifically adopted for this purpose. An analytical approach demands defining an interferential safety subject in air travel, characteristics of the security system and its components as well as defining the catalogue of the acts of unlawful interference, which constitute the introduction to their analysis.
\end{abstract}

\section{METODA BADANIA AKTÓW BEZPRAWNEJ INGERENCJI W LOTNICTWIE CYWILNYM}

\section{STRESZCZENIE}

Niniejszy artykuł ma na celu zaprezentowanie modelu systemu ochrony lotnictwa cywilnego w Polsce oraz autorskiego modelu badania aktów bezprawnej ingerencji w komunikacji lotni- 
czej w zaadoptowanej do tego celu teorii J. Reasona tzw. „modelu szwajcarskiego sera”. Analityczne podejście wymaga zdefiniowania interferencyjnego podmiotu bezpieczeństwa w komunikacji lotniczej, charakterystyki systemu ochrony i jego elementów składowych oraz określenia katalogu aktów bezprawnej ingerencji, stanowiących wprowadzenie do modelu ich badania. Określenie interferencyjnego podmiotu ochrony ma zasadnicze znaczenie z uwagi na fakt, że w szczególnych warunkach ten sam podmiot ochrony może być sprawcą bezprawnej ingerencji lub też podmiotem - elementem systemu sprawującego ochronę. 
